\title{
Study Site Research Coordinator
}

National Cancer Institute

\section{Source}

National Cancer Institute. Study Site Research Coordinator. NCI Thesaurus. Code C93358.

A person who handles the administrative responsibilities of a study on behalf of a study site, acts as a liaison between the study site and the study investig ator and/or study sponsor, and reviews all data and records before a monitor's visit. 